\title{
Effects of Muscarinic and Adrenergic Blockade on Growth Hormone Secretion Induced by Growth Hormone-Releasing Peptide-2 (GHRP-2) in Ovariectomized Ewes
}

\author{
SANG-Gun ROH, Minoru HIROTA, Mao Long HE, Nobuyoshi MATSUNAGA, \\ SATOSHI HIDAKA, AND HISASHI HIDARI \\ Department of Animal Science, Obihiro University of Agriculture and Veterinary Medicine, Obihiro 080, Japan
}

\begin{abstract}
This study was performed to investigate whether the blockade of cholinergic muscarinic and adrenergic pathways was involved in the GH-releasing effect of GH-releasing peptide-2 (GHRP-2) in ovariectomized ewes. Cholinergic muscarinic antagonist, atropine $(0.2 \mathrm{mg} / \mathrm{kg}$, iv, $15 \mathrm{~min}$ before GHRP2 administration) blunted the GH secretion caused by GHRP-2 (12.5 $\mu \mathrm{g} / \mathrm{kgBW})$. $\alpha$-Adrenergic antagonist phentolamine ( $15 \mu \mathrm{g} / \mathrm{kgBW} \cdot \mathrm{min}$, infusion from -15 to $30 \mathrm{~min}$ ) did not affect the GH response to GHRP-2, and $\beta$-adrenergic antagonist propranolol $(0.25 \mathrm{mg} / \mathrm{kgBW}$, iv, $15 \mathrm{~min}$ before GHRP2 administration) did not suppress the GHRP-2-induced GH release. These results showed that cholinergic muscarnic antagonist agent, atropine, exerts an inhibitory effect on GHRP-2-induced GH secretion in ovariectomized ewes.
\end{abstract}

Key words: GH-releasing peptide-2 (GHRP-2), GH, Muscarinic receptor, Adrenergic receptor

(Endocrine Journal 44: 861-865, 1997)

THE synthetic growth hormone (GH)-releasing peptide-2 (D-Ala-D- $\beta$ Nal-Ala-Trp-D-Phe-Lys- $\mathrm{NH}_{2}$, GHRP-2) releases GH in many species [1-3]. It is widely recognized that GHRPs for releasing GH act not only directly at the level of anterior pituitary receptor $[4,5]$, but also have a hypothalamic site of action through the intervention of the central nervous system [6, 7]. GHRP-6 (His-D-Trp-AlaTrp-D-Phe-Lys- $\mathrm{NH}_{2}$ ) infusion in the third ventricle has a minor effect on the pulsatile release of GHreleasing factor (GRF) and no effect on somatostatin (SS) secretion in conscious ewes [8]. GHRP-2 and GHRP-6 have been shown to induce $c$-fos activity in cells within the arcuate nucleus of the rat,

Received: February 26, 1997

Accepted: July 18, 1997

Correspondence to: Dr. Hisashi HIDARI, Department of Animal Science, Obihiro University of Agriculture and Veterinary Medicine, 2-11 Nishi, Inada-cho, Obihiro 080, Japan suggesting that they may activate GRF neurons [6, 7]. GHRP-6 was not unable to modify the changes in somatostatinergic tone induced by cholinergic muscarinic pathways in man and beagle $[9,10]$. Although $\alpha_{2}$-adrenergic receptor activation with clonidine did not alter the GH responses to GHRP6 , it was decreased by the $\alpha_{1}$-adrenergic receptor antagonist prazosin [9]. It could be thought that GHRPs induce the GH secretion via a hypophysiotropic pathway. In addition, unlike GHRP-6 and GHRP-1 (D-Ala-His-D- $\beta$ Nal-Ala-TrpD-Phe-Lys- $\mathrm{NH}_{2}$ ), there are species differences in the response of pituitary somatotrophs to GHRP-2 in sheep and rat pituitary cells [2]. This study was therefore conducted to determine whether the mechanism by which GHRP-2 acts is regulated by the blockade of the classical neurotransmitter systems in ovariectomized ewes. 


\section{Materials and Methods}

\section{Animals}

Six adult ovariectomized ewes were used (58-63 $\mathrm{kg}$ ). The ewes were housed in metabolic cages and fed alfalfa pellets at $2 \%$ of body weight in a single meal at $1600 \mathrm{~h}$. Water was available continuously. At least a week before the experiments, the polyethylene catheter for GHRP2 injection and blood sampling was inserted into a jugular vein, and was kept patent by daily flushing with a sterile solution of $3.8 \%$ trisodium citrate.

\section{Experimental procedures}

Experiments were performed in random order, and had a time interval of at least 1 week. Ewes were intravenously injected through the catheter with GHRP-2 dissolved in sterile saline at a dose of $12.5 \mu \mathrm{g} / \mathrm{kgBW}$. Serial blood samples were collected at $-30,-20,-10,0,5,10,15,20,25,30$, $40,50,60,75,90,105$ and $120 \mathrm{~min}$ after the injection of GHRP-2 or saline. Drugs were dissolved in $0.9 \%$ $\mathrm{NaCl}$ and injected via the catheter before the injection of GHRP-2. Atropine sulfate monohydrate (Wako Pure Chemical, Japan), a cholinergic muscarinic antagonist, was administered as a bolus injection at a dose of 0.2 $\mathrm{mg} / \mathrm{kg}$ iv $15 \mathrm{~min}$ before GHRP-2. To investigate the possible participation of an $\alpha$-adrenergic antagonist, phentolamine (Regitin, Ciba-Geigy, Japan) was infused at a dose of $15 \mu \mathrm{g} / \mathrm{ml} \cdot \mathrm{min}$ for $45 \mathrm{~min}$ from -15 to $30 \mathrm{~min}$. Blockade of $\beta$ adrenergic receptors was achieved by iv injection of propranolol $\cdot \mathrm{HCl}$ (Wako Pure Chemical, Japan) at a dose of $0.25 \mathrm{mg} / \mathrm{kg} 15 \mathrm{~min}$ before GHRP-2. The doses of atropine, phentolamine and propranolol were based on the previous report [11].

\section{Analysis}

The plasma concentrations of GH were assayed by RIA as previously reported [1]. The sensitivity was $0.5 \mathrm{ng} / \mathrm{ml}$, and inter- and intra-assay coefficients of variation were less than $10 \%$.

\section{Statistical analysis}

For each study, plasma GH concentrations (mean \pm SEM) were plotted against time for each ewe. The GH AUC ( $\mathrm{ng} / \mathrm{ml} \cdot \mathrm{min})$ was calculated by a trapezoidal method from -30 to $120 \mathrm{~min}$ in each ewe. Significant differences between AUCs were analyzed by analysis of variance (ANOVA) followed by Duncan's multiple range test.

\section{Results}

GHRP-2 (12.5 $\mu \mathrm{g} / \mathrm{kgBW})$ elicited a striking rise in the plasma GH concentration with peak levels occurring at 15-25 min in ewes (Fig. 1). Compared to the saline control, iv injection of GHRP-2 increased $\mathrm{GH}$ concentrations with an 8 -fold increase in the peak GH concentration $(16.3 \pm 2.5$ $\mathrm{ng} / \mathrm{ml}$ ) at the $12.5 \mu \mathrm{g} / \mathrm{kgBW}$ dose. GH AUC at the injection of saline after the injection of GHRP-2 was significantly greater than that obtained on the treatment of saline and saline as a control $(990.8 \pm$ 136.3 vs. $390.1 \pm 29.3 \mathrm{ng} / \mathrm{ml} \cdot \mathrm{min} \pm \mathrm{SEM} ; P<0.01$ ) (Table 1). The injection of saline after pretreatment with atropine did not change the resting $\mathrm{GH}$

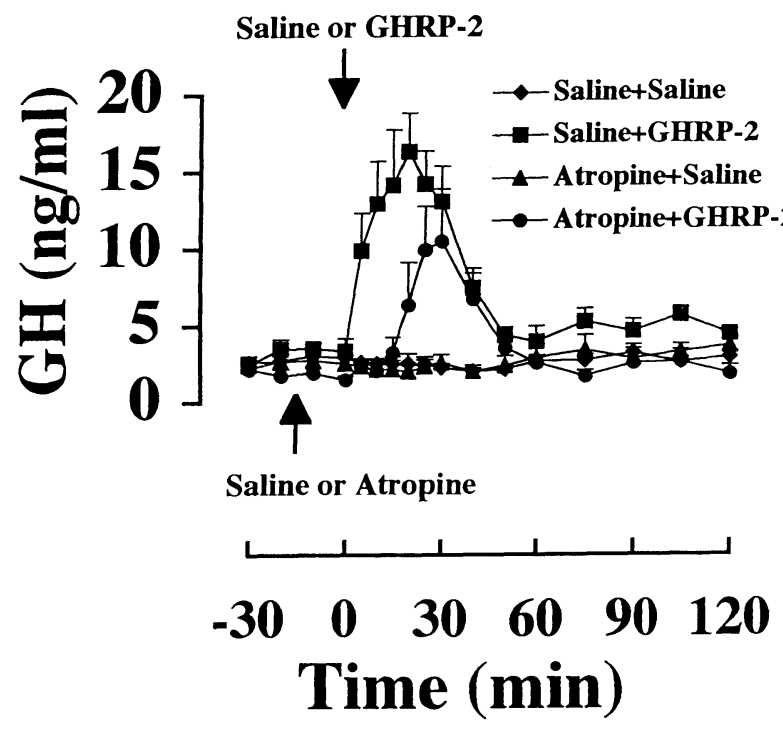

Fig. 1. Effect of iv administration of GHRP-2 $(12.5 \mu \mathrm{g} / \mathrm{kg}$ $\mathrm{BW}$, iv, $0 \mathrm{~min})$ after pretreatment with atropine $(0.2$ $\mathrm{mg} / \mathrm{kg} \mathrm{BW}$, at $-15 \mathrm{~min}$ ) on plasma GH levels (mean $\pm \mathrm{SEM}$ ) in six ewes. 
Table 1. GH AUC (mean \pm SEM) to saline or GHRP-2 injection after pretreatment with all the different drugs tested in six ewes*

\begin{tabular}{llc}
\hline Drug & & GH AUC \\
\hline Saline & Saline & $390.1 \pm 29.3$ \\
Atropine & Saline & $401.0 \pm 70.0$ \\
Phentolamine & Saline & $365.8 \pm 61.6$ \\
Propranolol & Saline & $398.5 \pm 116.9$ \\
\hline Saline & GHRP-2 & $990.8 \pm 136.3^{\mathrm{a}}$ \\
Atropine & GHRP-2 & $502.0 \pm 79.5^{\mathrm{b}}$ \\
Phentolamine & GHRP-2 & $970.6 \pm 133.4^{\mathrm{a}}$ \\
Propranolol & GHRP-2 & $1032.3 \pm 144.2^{\mathrm{a}}$ \\
\hline
\end{tabular}

${ }^{*} \mathrm{GH}$ AUCs were calculated from -30 to $120 \mathrm{~min}$. GHRP-2 $12.5 \mu \mathrm{g} / \mathrm{kg}$ iv; atropine $0.2 \mathrm{mg} / \mathrm{kg}$ iv; phentolamine $15 \mu \mathrm{g} /$ $\mathrm{kg} \cdot \mathrm{min}$ iv; propranolol $0.25 \mathrm{mg} / \mathrm{kg}$ iv. a Means significant difference between saline and GHRP-2 on same drug treatment $(P<0.01)$. $\mathrm{b}$ Means significant difference among the GHRP-2 injections on all the different drugs in the lower part $(P<0.01)$.

concentration, but atropine suppressed the GH release caused by GHRP-2. The mean peak concentration was lower in the pretreatment of atropine after the injection of GHRP-2 (10.5 \pm 3.4 $\mathrm{ng} / \mathrm{ml})$ than in saline plus GHRP-2 $(16.3 \pm 2.5 \mathrm{ng} /$ $\mathrm{ml}$ ). GH AUC on atropine plus GHRP-2 was significantly lower than on saline plus GHRP-2 $(P<0.01)$ (Table 1$)$.

Figure 2 indicates the effects of phentolamine and propranolol on the $\mathrm{GH}$ secretion caused by GHRP-2. Infusion of phentolamine did not change the GH secretion elicited by GHRP-2 (Fig. 2a). The GH AUC after the treatment with saline plus GHRP-2 was similar to that on phentolamine plus GHRP-2 (990.8 \pm 136.3 vs. $970.6 \pm 133.4$ ) (Table 1). Propranolol after the injection of saline did not change the basal concentration of $\mathrm{GH}$, and pretreatment of propranolol did not attenuate the GH release caused by GHRP-2 (Fig. 2b). There was no significant difference between propranolol + GHRP-2 and saline + GHRP-2 in GH AUC.

\section{Discussion}

Although the mechanisms of action of GHRP-2 have not been fully established, there is probably a dual site of action on the pituitary and hypothalamus, possibly involving regulatory
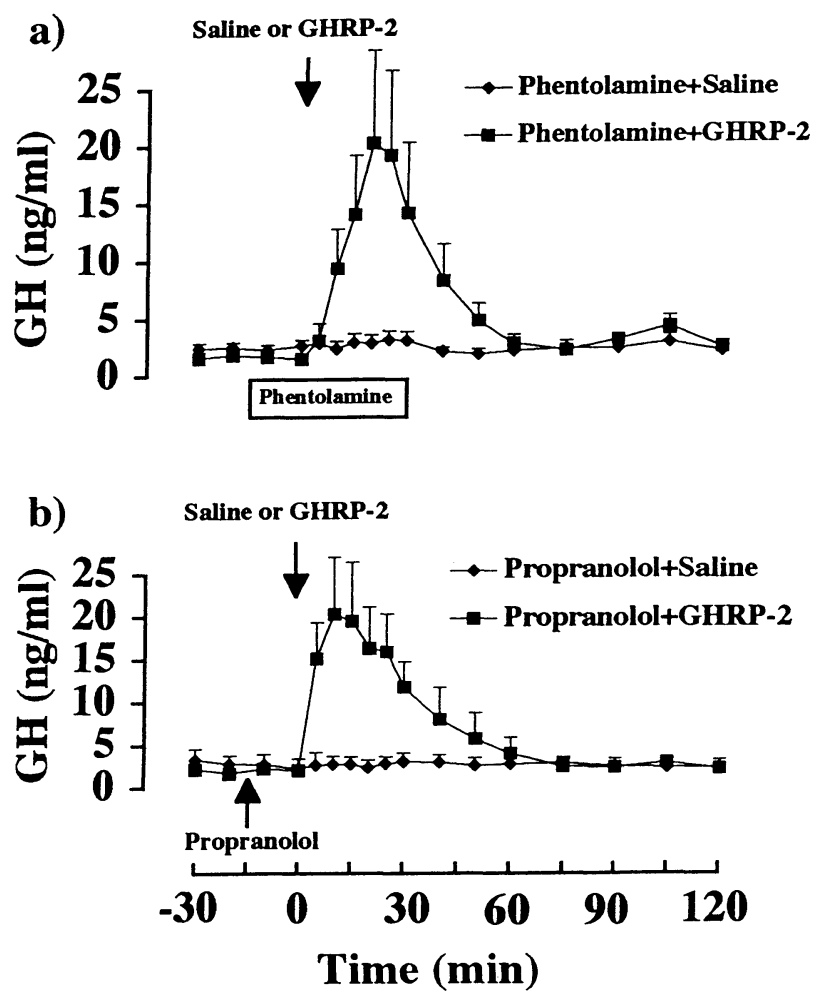

Fig. 2. Effect of iv administration of GHRP-2 (12.5 $\mu \mathrm{g} / \mathrm{kg}$ $B W$, iv, $0 \mathrm{~min}$ ) after pretreatments with phentolamine and propranolol on plasma GH levels (mean \pm SEM) in six ewes. Phentolamine (15 $\mu \mathrm{g} /$ $\mathrm{kgBW} \cdot \mathrm{min}$ ) was continuously infused from -15 to $30 \mathrm{~min}$. Propranolol $(0.25 \mathrm{mg} / \mathrm{kg} \mathrm{BW})$ was injected at -15 min before GHRP-2.

factors in addition to GRF and SS. The early studies on the GHRPs suggested a major mode of action at the level of the pituitary, but in more recent years it has been suggested that GHRPs also have, at least in part, a direct effect on the hypothalamus $[2,12]$. The secretion of GRF and SS are governed by a host of neuropeptides and neurotransmitters that provide a functional link between higher central nervous system and hypophysiotropic neurons. Factors that have been implicated include the biogenic amines, e.g. acetylcholine, adrenaline, dopamine, serotonin, histamine, etc. [13, 14]. Indeed, the fact that GHRPs are much more potent in vivo than in vitro suggested that GHRPs are closely related to these factors [2,4].

It is now widely accepted that a cholinergic muscarinic pathway plays a major role in GH secretion [15]. Atropine (100 $\mu \mathrm{g}$, iv), which acts by 
increasing hypothalamic SS release, completely abolished the stimulatory action of GHRP-6 in adult beagles [9]. Administration of atropine ( $1 \mathrm{mg}, \mathrm{im})$ completely prevented the GH responses to GHRP6 in man [10], but in an experimental setting of low somatostatinergic tone due to pyriodstigmine, GHRP-6 is capable of increasing the GH response $[9,10]$. An increase and decrease in $\mathrm{GH}$ responses to GHRP-6 following administration of cholinergic agonist and antagonist respectively indicated that GHRP-6 is unable to modify the changes in somatostatinergic tone induced by cholinergic muscarnic pathways. In our results the administration of atropine blunted the GH responses to GHRP-2 in ewes. These results suggested that the inhibitory effect of atropine on GHRP-2-induced GH release is mediated by the increase in hypothalamic SS release, but the GH response to GHRP-2 was not completely inhibited by atropine in contrast to GHRP-6 in Beagle [9]. It seems to be that besides a chorinergic muscarinic pathway there may possibly be GH secretion to GHRP-2 via another neural pathway.

Adrenergic mechanisms participate in the regulation of GH secretion, $\alpha$ - and $\beta$-adrenergic receptors having, respectively, stimulatory or inhibitory effects [15], but in ovine pituitary cells $\alpha_{2}$-adrenergic receptors induce the inhibitory actions of adrenergic agonists, while $\alpha_{1^{-}}$and $\beta$ adrenergic receptors appear to mediate the stimulatory actions of adrenergic agonists on GH release [16]. Evidence has accumulated during the last few years indicating that adrenergic neurons participate in the regulation of the normal pulsatile $\mathrm{GH}$ secretion [14]. In view of these facts, $\alpha-$ and $\beta$ adrenergic receptors, located either in the hypothalamus or in the pituitary, are an indispensable prerequisite for $\mathrm{GH}$ secretion, but our results showed that the GH secretion caused by GHRP-2 occurs independent of $\alpha$ - and $\beta$ adrenergic receptors. Although administration of the $\alpha_{1}$-adrenergic receptor antagonist prazosin (20 $\mathrm{mg}$, iv) reduced GHRP-6-induced GH secretion, $\alpha_{2}$-adrenergic agonist clonidine did not influence the GHRP-6-induced GH secretion [9]. These results indicated that although the adrenergic system participates in physiological regulation of GH secretion, GHRP-2 does not have a direct action via this pathway.

In conclusion, this study showed that the effect of GHRP-2 on GH secretion was blunted by a cholinergic muscarinic blockade with atropine, but the blockade of adrenergic receptor did not attenuate the GHRP-2-induced GH release in ovariectomized ewes.

\section{Acknowledgement}

We are grateful to the NHPP of NIDDK for supplying the reagents and procedures for GH RIA. We also greatly thank Kaken Pharmaceutical Company for providing us with GHRP-2 (KP102).

\section{References}

1. Roh SG, Matsunaga N, Hidaka S, Hidari H (1996) Characterization of growth hormone secretion responsiveness to growth hormone-releasing peptide-2 (GHRP-2 or KP102) in calves. Endocr J 43: 291-298.

2. Chen C, Wu D, Clarke IJ (1996) Signal transduction systems employed by synthetic GH-releasing peptides in somatotrophs. J Endocrinology 148: 381386.

3. Sawada H, Sugihara H, Onose H, Minami S, Shibasaki T, Wakabayashi I (1994) Effect of D-AlaD- $\beta$ Nal-Ala-Trp-D-Phe-Lys- $\mathrm{NH}_{2}$ (KP-102) on GH secretion in urethan-anesthetized rats. Regulatory Peptides 53: 195-201.

4. Korbonits M, Grossman AB (1995) Growth hormone-releasing peptide and its analogues. Trends Endocrinol Metab 6: 43-49.

5. Wu D, Chen C, Zhang J, Bowers CY, Clarke IJ (1996) The effects of GH-releasing peptide-6 (GHRP-6) and GHRP-2 on intracellular adenosine $3^{\prime}, 5^{\prime}$ monophosphate (cAMP) levels and GH secretion in ovine and rat somatotrophs. J Endocrinology 148: 197-205.

6. Kamegai J, Hasegawa O, Minami S, Sugihara $H$, Wakabayashi I (1996) The growth hormonereleasing peptide KP102 induced $c$-fos expression in the arcuate nucleus. Molecular Brain Res 39: 153159.

7. Dickson SL, Leng G, Robinson ICAF (1993) Systemic administration of growth hormone-releasing 
peptide activates hypothalamic arcuate neurons. Neuroscience 53: 303-306.

8. Fletcher TP, Thomas GB, Clarke IJ (1996) Growth hormone-releasing hormone and somatostatin concentrations in the hypophysial portal blood of conscious sheep during the infusion of growth hormone-releasing peptide-6. Domest Anim Endocrinol 13: 251-256.

9. Muruais J, Peñalva A, Dieguez C, Casanueva FF (1993) Influence of endogenous cholinergic tone and $\alpha$-adrenergic pathways on growth hormone responses to His-D-Trp-Ala-Trp-D-Phe-Lys- $\mathrm{NH}_{2}$ in the dog. J Endocrinology 138: 211-218.

10. Peñalva A, Carballo A, Pombo M, Casanueva EF, Dieguez C (1993) Effect of growth hormone (GH)releasing hormone (GHRH), atropine, pyridostigmine, or hypoglycemia on GHRP-6induced GH secretion in man. J Clin Endocrinol Metab 76: 168-171.

11. Bloom SR, Edwards AV (1984) Characterization of the neuroendocrine responses to stimulation of the splanchnic nerves in bursts in the conscious calf. $J$ Physiology [Lond] 346: 533-545.

12. Bowers CY, Reynolds GA, Barrera CM (1991) A second generation $\mathrm{GH}$ releasing peptide heptapeptide [abst 1566] In: 73rd Annual Meeting of the Endocrine Society, Washington, DC, June 1991, Bethesda, MD, The Endocrine Society.

13. Buonomo FC, Baile CA (1990) The neurophysiological regulation of growth hormone secretion. Domest Anim Endocrinol 7: 435-450.

14. Frohman LA, Downs TR, Chomczynski P (1992) Regulation of growth hormone secretion. Front in Neuroendocrinology 13: 344-405.

15. Müller EE (1987) Neural control of somatotropic function. Physiol Rev 67: 962-1053.

16. Soyoola EO, Burgess MF, Bird RC, Kemppainen RJ, Williams JC, Sartin JL (1994) Neurotransmitter receptor agonists regulates growth hormone gene expression in cultured ovine pituitary cells. Proc Soc Exp Biol Med 207: 26-33. 